Article

\title{
Grassland Establishment of Dwarf Napiergrass (Pennisetum purpureum Schumach) by Planting of Cuttings in the Winter Season
}

\author{
Satoru Fukagawa ${ }^{1}$ and Yasuyuki Ishii ${ }^{2, *}$ \\ 1 Nagasaki Agricultural and Forestry Technical Development Center, Shimabara, Nagasaki 859-1404, Japan; \\ s.fukagawa-123@pref.nagasaki.lg.jp \\ 2 Faculty of Agriculture, University of Miyazaki, Miyazaki 889-2192, Japan \\ * Correspondence: yishii@cc.miyazaki-u.ac.jp; Tel.: +81-985-58-7251
}

Received: 10 November 2017; Accepted: 24 January 2018; Published: 28 January 2018

\begin{abstract}
We investigated a new method for the establishment of dwarf Napiergrass by covering stem cuttings with soil in the winter season analogously to summer establishment in sugarcane. Three experiments were conducted, including measuring the labor involved in plant establishment, and an extension study was applied to livestock producers' fields in two locations. Using this technique, we obtained an emerged plant density of over two plants $/ \mathrm{m}^{2}$. Moreover, this proved a simple and labor-saving method compared with manual or mechanical transplanting. Sowing of Italian ryegrass at the same time as covering cuttings of dwarf Napiergrass with soil could control spring weed growth without disturbing the emergence of dwarf Napiergrass, suggesting the feasibility of a double-cropping forage production system in the region.
\end{abstract}

Keywords: dwarf Napiergrass; nursery production; underground storage; winter season

\section{Introduction}

A dwarf variety of the late-heading type of Napiergrass (Pennisetum purpureum Schumach) shows high winter survival in northern [1,2] and southern [3,4] Kyushu, Japan. This grass can yield dry matter (DM) at $20 \mathrm{t} /$ ha in the second year after establishment [1]. At the current experimental sites, dwarf Napiergrass is cultivated as a perennial species and it can be incorporated into the cropping system with winter annual Italian ryegrass (Lolium multiflorum Lam, IR). Therefore, a summer crop of dwarf Napiergrass has been cultivated for several years without the need for replanting, with IR oversown into the interrow space in late autumn, every year. We revealed that dwarf Napiergrass is a promising tropical grass for beef cow-calf producers in these regions [1,5]. However, currently, dwarf Napiergrass consists of a single genotype, and no selection or breeding of this genotype has been conducted yet in the current site.

According to previous research, dwarf Napiergrass can be utilized not only under a cut-and-carry system [5], but also in silage processing [1,2,6-14] and under grazing management [5,15-18] because of its herbage quality, which is not so low as ordinary tropical grasses such as guineagrass (Panicum maximum) and sudangrass (Sorghum sudanense) $[1,2,19]$. Moreover, the nutritive value of dwarf Napiergrass was the highest among genotypes of Napiergrass [20-24]. However, since dwarf Napiergrass produces almost no viable seed, transplanting nursery plants by hand has been the sole method of establishment. Manual transplanting is hard work, requiring bending at the waist, and therefore cannot be easily adopted, especially for aged beef cow-calf producers. Moreover, the planting season is ordinarily from spring to summer, when farming operations are especially busy, so it is difficult to dedicate the time to transplanting vegetation without overlapping with other farming operations. 
Sollenberger et al. [25] developed a means for mechanical transplanting using a prototype semi-automated Napiergrass planter that a worker could ride to set out nursery plants. Utamy et al. [26] reported completing the entire process of nursery production and establishment of dwarf Napiergrass, from preparation of stem cuttings based on aerial tiller buds, to cell-tray culture in a glasshouse over winter, performing mechanical transplanting using a Welsh onion planter. Murata et al. [27] also reported that cell-tray nursery plants of dwarf Napiergrass can be transplanted by a vegetable or potato planter. This planting method led to reduced labor compared to a manual method [27]. Therefore, a mechanical transplanting method must be developed for cell-tray nursery plants, as along with a machine suitable for transplanting them, to reduce labor intensity such as the bending at the waist required by the manual method. Maruta et al. [27] also developed a way to transplant dwarf Napiergrass by hand scattering and soil packing of cell-tray nursery plants, although the field transplanting method depends on soil moisture conditions, and would only be successful before a rainy day.

In trials of underground storage of stem sections of dwarf Napiergrass, Iki et al. [28] reported that storage of ten-node stem sections planted at depths of 25 and $40 \mathrm{~cm}$ achieved an emergence of $80 \%$, higher than at $10 \mathrm{~cm}$ or the emergence of one-node sections at any planting depth. Napiergrass is established in a manner similar to that used for sugarcane (Saccharum officinarum L.) [29], which is usually produced from stem cuttings called setts, with each node having the potential to grow a new plant. Sugarcane shoots grow from underground nodes, and the axillary buds at these nodes give rise to tillers [30]. Sugarcane is usually established by placing setts underground during the period from spring to summer in Japan.

Thus, by applying the method used for sugarcane while placing setts underground in the modified late-autumn season when the axillary buds of Napiergrass mature, we aimed to develop a labor-saving method of establishing dwarf Napiergrass by planting stem cuttings with soil in the winter season when farming operations are generally limited.

\section{Materials and Methods}

\subsection{Grass Species, Experiment Design and Site Description}

The dwarf variety of a late-heading type of Napiergrass (Pennisetum purpureum Schumach) was derived from material brought from Florida, USA via Thailand to the University of Miyazaki, Japan in 1996 [3,31], and the variety was introduced by the University of Miyazaki to Nagasaki Prefecture, Japan in 2002. After this variety was introduced at the University of Miyazaki, it was maintained in field conditions without any genetic improvement. The plant shape is quite similar to the variety "Mott". The origin of this dwarf Napiergrass has already been reported [31]. This variety was examined for feasibility of propagation from cuttings planted in the field at the Livestock Research Division, Nagasaki Agricultural and Forestry Technical Development Center in Shimabara, Nagasaki $\left(32^{\circ} 42^{\prime} \mathrm{N}\right.$, $128^{\circ} 39^{\prime} \mathrm{E}$, about $120 \mathrm{~m}$ above sea level (a.s.l.)), referred to here as Shimabara, in two winter seasons, 2014-2015 and 2015-2016.

In Experiment 1, to determine the feasibility of using stem-cuttings planted in the field for propagation of dwarf Napiergrass in the winter season, compared with the conventional method of plant establishment, we investigated the missing plant rate and density of plants that emerged in the spring after planting in late November using our cultivation method. Moreover, we measured labor, in terms of both time and number of people required, compared with the manual method. Labor was based on all activities from furrowing to placing and covering stem cuttings with soil. The labor for the manual establishment method was measured for transplanting rooted tillers of dwarf Napiergrass at 2 plants $/ \mathrm{m}^{2}$ with $1 \mathrm{~m}$ interrow and $0.5 \mathrm{~m}$ intrarow spacing into $500 \mathrm{~m}^{2}$ on 24 May 2013, performed in the manner described in our previous study $[9,10]$.

In Experiment 2, we investigated the feasibility of field propagation in more detail by determining the optimum timing and depth of planting of stem cuttings horizontally with and without concurrent 
sowing of Italian ryegrass (Lolium multiflorum Lam., IR, cv. Waseyutaka) during the winter season in 2015-2016.

In Experiment 3, we extended the cutting propagation technique to two sites of beef cow-calf producers, one on a remote island in Miraku, Goto, Nagasaki Prefecture $\left(32^{\circ} 56^{\prime} \mathrm{N}, 130^{\circ} 20^{\prime} \mathrm{E}\right.$, about $10 \mathrm{~m}$ a.s.l.), referred to here as Goto, and the other on Kyushu Island in Konagai, Isahaya, Nagasaki Prefecture $\left(32^{\circ} 56^{\prime} \mathrm{N}, 130^{\circ} 9^{\prime} \mathrm{E}\right.$, about $200 \mathrm{~m}$ a.s.l.), referred to here as Isahaya. We examined the missing plant rate and plant density in the spring after planting in early December.

\subsection{General Protocol for Winter Field Propagation of Cuttings of Dwarf Napiergrass}

A flow chart of the propagation of cuttings of dwarf Napiergrass in the winter season is presented in Figure 1. Stem cuttings of hardened elongated internodes of dwarf Napiergrass were obtained by defoliating leafage using a hand cutter during the period from late November to December. Therefore, one stem cutting typically had more than 10 nodes. We furrowed to a $10 \mathrm{~cm}$ depth with $1 \mathrm{~m}$ interrow spacing, where we placed stem cuttings and covered them with soil. Thereafter, IR was sown by broadcasting at $2 \mathrm{~g} / \mathrm{m}^{2}$ without pressing the soil with a land roller to avoid the risk of exposing stem cuttings above the ground. IR was harvested three times monthly from April to June, after which dwarf Napiergrass would emerge to complete the grassland establishment.

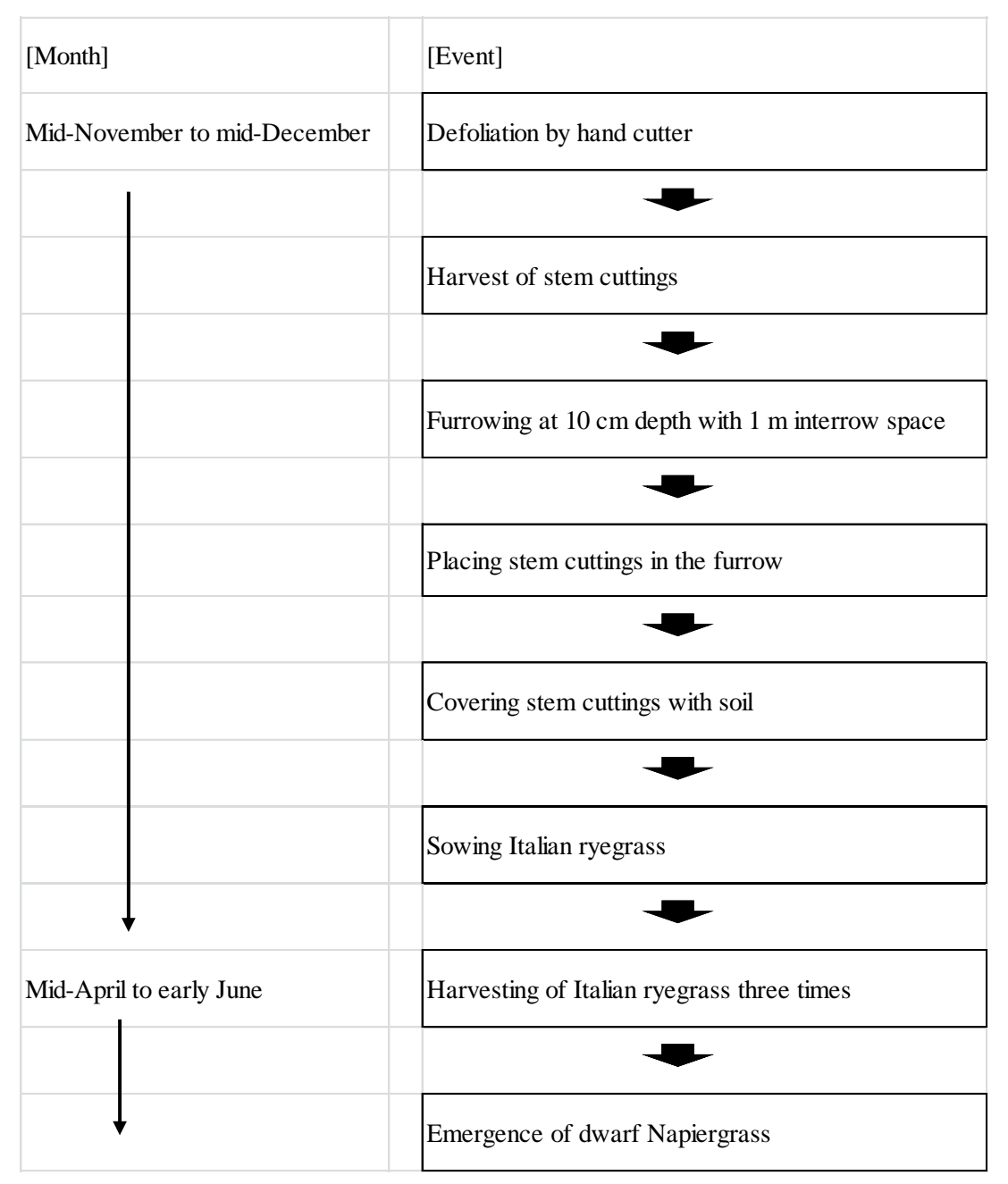

Figure 1. Flow chart of production from stem cuttings of dwarf Napiergrass planted in the field in winter. 


\subsection{Experimental Details at Each Step of Field Propagation of Cuttings}

\subsubsection{Planting in 2014-2015 and in 2015-2016 Seasons (Experiment 1)}

The experimental plot area was $34 \mathrm{~m}^{2}(2 \mathrm{~m} \times 17 \mathrm{~m})$ and was established in a randomized complete block design with three replications. Stem cuttings of dwarf Napiergrass were placed underground at a $10 \mathrm{~cm}$ depth (IR-10 cm plot) and IR was sown at $2 \mathrm{~g} / \mathrm{m}^{2}$ on 22 November 2014 and on 16 November 2015, respectively. Chemical compound fertilizer with $10 \mathrm{~g} / \mathrm{m}^{2}$ each of $\mathrm{N}_{2} \mathrm{P}_{2} \mathrm{O}_{5}$ and $\mathrm{K}_{2} \mathrm{O}$ was top-dressed at sowing and was top-dressed again after the first and second harvest with $5 \mathrm{~g} / \mathrm{m}^{2}$ of both $\mathrm{N}$ and $\mathrm{K}_{2} \mathrm{O}$. After the third harvest of IR, we examined the dwarf Napiergrass missing plant rate and plant density the following spring. The missing plant rate was the percentage of cuttings that failed to sprout new growth and was determined by the sum of the length of missing plants where the missing length was longer than $1 \mathrm{~m}$, divided by row length $(17 \mathrm{~m})$ and multiplied by 100 .

\subsubsection{Time and Depth of Planting in 2015-2016 (Experiment 2)}

A second set of stem cuttings of dwarf Napiergrass were placed underground at a depth of $10 \mathrm{~cm}$ on 16 November 2015. In one plot (IR-10 cm plot), IR was sown at $2 \mathrm{~g} / \mathrm{m}^{2}$, and in a control plot, no IR was sown. Stem cuttings were placed in rows with a $20 \mathrm{~cm}$ depth on 1 December 2015, at the same time as IR was sown (IR-20 cm plot). The DM yield of IR was investigated for both the IR-10 $\mathrm{cm}$ and IR-20 $\mathrm{cm}$ plots and weed DM was determined for the control plot. Fertilizer application and the determination of the missing plant rate, assessed after the third harvest of IR, were the same as in Experiment 1.

\subsubsection{Extended Field Experiment in 2015-2016 (Experiment 3)}

A practical field experiment for propagation of dwarf Napiergrass by cuttings in the winter season was conducted at Isahaya, with planting on 2 December 2015, and at Goto, with planting on 8 December 2015. After the third harvest of IR, the missing plant rate and emerged plant density of dwarf Napiergrass were investigated by the same procedure as in Experiment 1.

\subsection{Plant Growth and DM Yield}

Plant height of both IR and dwarf Napiergrass was determined at harvest, when plants were defoliated at $10 \mathrm{~cm}$ above the ground surface in a $1 \mathrm{~m}$ square with three replications. A random sampling method was applied by throwing a quadrat to fall at random within the site. The DM weight of each grass was determined after oven-drying at $70{ }^{\circ} \mathrm{C}$ for $72 \mathrm{~h}$ to calculate DM yield.

\subsection{Meteorological Conditions}

Changes in monthly meteorological parameters are shown in Figure 2 for the daily mean air temperature and precipitation during the current experiment in 2014-2016 and in a normal year, defined as the average over the period 1980-2010, based on data from the Nagasaki Local Meteorological Observatory. Daily mean temperature in the current experimental year was almost the same or slightly higher than in a normal year at both the Shimabara and Goto sites. Monthly precipitation was almost the same as or higher than that in a normal year, except for the extremely low precipitation in February and August 2015 at the Shimabara site, and in February 2016 at the Goto site. 


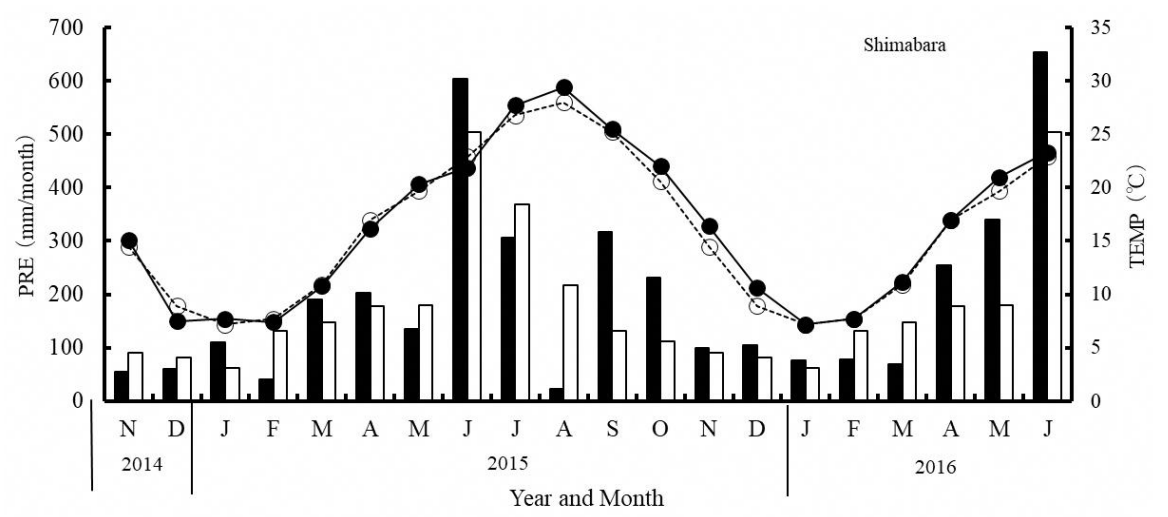

(a)

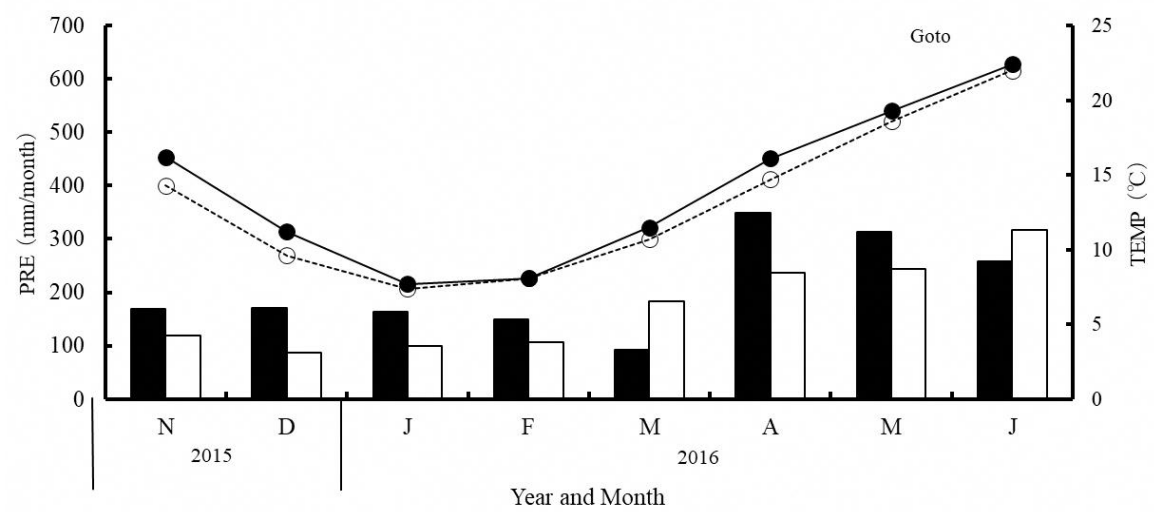

(b)

Figure 2. Changes in the monthly meteorological parameters of daily mean air temperature (TEMP) and precipitation (PRE) during the experiment in 2014-2016 and in a normal year (NY), averaged in 1980-2010 at the Shimabara site and averaged in 2006-2015 at the Goto site. TEMP: 2014-2016 (•),

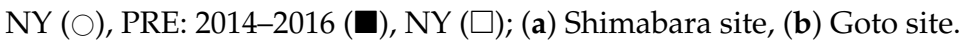

\subsection{Statistical Analysis}

Data were analyzed by one-way analysis of variance, using StatView for Windows software ver. 5.0 (SAS Institute Inc., Cary, NC, USA) for Experiments 1-3. Differences between means were evaluated at $5 \%$ probability using a Tukey-Kramer procedure.

\section{Results}

\subsection{Effect of Planting Depth and Planting Site}

The missing plant rate and plant density in the following spring are shown in Table 1 for the propagation of cuttings of dwarf Napiergrass in the winter season. The missing plant rate was $6.8 \%$ in 2015 and $8.1 \%$ in 2016 in Shimabara, where the planting depth was fixed at $10 \mathrm{~cm}$. On the other hand, the missing plant rate at a $20 \mathrm{~cm}$ depth was $37 \%$, which was four times that at a $10 \mathrm{~cm}$ depth.

The missing plant rate in the extended producer's fields at Goto $(10 \mathrm{~m}$ a.s.l.) and Isahaya (200 $\mathrm{m}$ a.s.1.) at a $10 \mathrm{~cm}$ depth was $7.3 \%$ and $17.6 \%$, respectively. The emerged plant density across the three sites was maintained above 2 plants $/ \mathrm{m}^{2}$. 
Table 1. Missing plant rate and emerged plant density the spring following planting of dwarf Napiergrass cuttings in Experiments 1-3.

\begin{tabular}{|c|c|c|c|c|c|c|}
\hline Experiment & $\begin{array}{c}\text { Site } \\
\text { (Altitude) }\end{array}$ & Soil Type ${ }^{1}$ & $\begin{array}{l}\text { Planting Date } \\
\text { (Date-Month-Year) }\end{array}$ & $\begin{array}{l}\text { Experimental } \\
\text { Plot }\end{array}$ & $\begin{array}{l}\text { Missing Plant } \\
\text { Rate (\%) }\end{array}$ & $\begin{array}{c}\text { Emerged Plant } \\
\left.\text { Density (plants } / \mathrm{m}^{2}\right)\end{array}$ \\
\hline Exp. 1 & $\begin{array}{l}\text { Shimabara } \\
(120 \mathrm{~m})\end{array}$ & $\begin{array}{l}\text { Fine-grained } \\
\text { yellow }\end{array}$ & 22-Nov-2014 & IR-10 cm & $6.8^{\mathrm{b} 2}$ & $2.5^{\mathrm{ab} 2}$ \\
\hline Exp. 2 & $\begin{array}{l}\text { Shimabara } \\
(120 \mathrm{~m})\end{array}$ & $\begin{array}{l}\text { Fine-grained } \\
\text { yellow }\end{array}$ & $\begin{array}{l}\text { 16-Nov-2015 } \\
\text { 1-Dec-2015 }\end{array}$ & $\begin{array}{l}\text { IR-10 cm } \\
\text { IR-20 cm }\end{array}$ & $\begin{array}{l}8.1^{\mathrm{b}} \\
37.1^{\mathrm{a}}\end{array}$ & $\begin{array}{l}3.4^{\mathrm{a}} \\
-3\end{array}$ \\
\hline \multirow[t]{2}{*}{ Exp. 3} & $\begin{array}{l}\text { Goto } \\
(10 \mathrm{~m})\end{array}$ & $\begin{array}{l}\text { Medium-coarse } \\
\text { yellow }\end{array}$ & 8-Dec-2015 & IR-10 cm & $17.6^{\mathrm{b}}$ & $2^{b}$ \\
\hline & $\begin{array}{l}\text { Isahaya } \\
(200 \mathrm{~m})\end{array}$ & $\begin{array}{l}\text { Fine-grained } \\
\text { dark red }\end{array}$ & 2-Dec-2015 & IR-10 cm & $7.3^{b}$ & $2.4^{\mathrm{ab}}$ \\
\hline
\end{tabular}

Notes: ${ }^{1}$ Source: Derived from The Fourth Committee for Soil Classification and Nomenclature, The Japanese Society of Pedology (2003); ${ }^{2}$ The values with different superscripted letters $\left({ }^{a-b}\right)$ within the same column are significantly different at the $5 \%$ level by Tukey and Kramer test; ${ }^{3}$ Not determined.

\subsection{Effect of Planting Time and Sowing of IR}

The missing plant rate and plant density of overwintered dwarf Napiergrass and the DM yield of dwarf Napiergrass and IR are shown in Table 2 (Experiment 2). In the November planting, the missing plant rate did not differ significantly between the control plot and IR-10 $\mathrm{cm}$ plot. Sowing of IR had a negligible effect on the emergence of dwarf Napiergrass in field production from cuttings. When planting was delayed to mid-December, the missing plant rate in the IR-10 cm plot did not differ significantly from the other two plots planted in November. The emerged plant density was maintained in a range of 2.9 to 3.8 plants $/ \mathrm{m}^{2}$.

Comparing yields of IR and weeds, the triple-cut IR DM yield of the IR-10 cm plot in November and December plantings with sowing of IR were significantly higher than the weed yield of the control plot. No significant differences in the DM yield of dwarf Napiergrass existed among the three plots. The annual total DM yield in the IR- $10 \mathrm{~cm}$ plot planted in December reached $24.0 \mathrm{Mg} / \mathrm{ha}$, though it was inferior to the yields in the other two plots.

Table 2. Missing plant rate and emerged plant density of dwarf Napiergrass and dry matter (DM) yield of dwarf Napiergrass and Italian ryegrass (IR) in the spring following planting of cuttings at Shimabara (Experiment 2).

\begin{tabular}{|c|c|c|c|c|c|c|}
\hline \multirow{2}{*}{ Experimental Plot } & \multirow{2}{*}{$\begin{array}{c}\text { Planting Date } \\
\text { (Date-Month-Year) }\end{array}$} & \multirow{2}{*}{$\begin{array}{l}\text { Missing Plant } \\
\text { Rate (\%) }\end{array}$} & \multirow{2}{*}{$\begin{array}{c}\text { Emerged Plant } \\
\text { Density } \\
\text { (plants/m2) }\end{array}$} & \multicolumn{2}{|c|}{$\begin{array}{l}\text { Triple-Cut DM } \\
\text { Yield (Mg/ha) }\end{array}$} & \multirow{2}{*}{$\begin{array}{c}\text { Total DM } \\
\text { Yield (Mg/ha) }\end{array}$} \\
\hline & & & & IR or weed & $\begin{array}{c}\text { Dwarf } \\
\text { Napiergrass }\end{array}$ & \\
\hline $\begin{array}{c}\text { IR-10 cm, } \\
\text { November planting }\end{array}$ & 16-Nov-2015 & $8.1^{\mathrm{ns} 1}$ & $3.4^{\mathrm{ns} 1}$ & $14.9^{\text {a } 1}$ & $15.2^{\text {ns } 1}$ & $30.1^{\mathrm{a} 1}$ \\
\hline $\begin{array}{l}\text { Control (no IR } \\
\text { sowing and } 10 \mathrm{~cm} \\
\text { November planting) }\end{array}$ & 17-Nov-2015 & 5.1 & 3.8 & $8.2^{c}$ & 17.4 & $25.6^{a b}$ \\
\hline $\begin{array}{l}\text { IR-10 cm, December } \\
\text { planting }\end{array}$ & 17-Dec-2015 & 6.3 & 2.9 & $10.1^{\mathrm{b}}$ & 13.9 & $24.0^{\mathrm{b}}$ \\
\hline
\end{tabular}

Notes: ${ }^{1}$ Values with different superscripted letters $\left({ }^{(a-c}\right)$ in the same column are significantly different at the $5 \%$ level by a Tukey and Kramer test; ${ }^{\text {ns }}$ Not significant.

\subsection{Labor}

The effect of establishment method for dwarf Napiergrass on labor is shown in Table 3. The labor for manual transplanting (control), engaging 7 persons, and for propagation of cuttings of dwarf Napiergrass in the winter season, engaging 2 persons, was 140 and 47.7 person h/ha, respectively. Thus, field propagation of cuttings reduced labor by $66 \%$. 
Table 3. Effect of dwarf Napiergrass establishment on labor (Experiment 1).

\begin{tabular}{ccc}
\hline Method & Number of People Engaged & Labor $^{\mathbf{1}}$ (Person h/ha) (\% of Control) \\
\hline Planting of cuttings in the winter & 2 & $47.7^{\mathrm{b} 2}(34)$ \\
Manual transplanting (control) & 7 & $140^{\mathrm{a}}(100)$ \\
\hline Notes: ${ }^{1}$ Labor was calculated from furrowing to placing and covering stem cuttings with soil; ${ }^{2}$ Values with different \\
lowercase letters $\left({ }^{\mathrm{a}-\mathrm{b}}\right)$ within the same column are significantly different at the $5 \%$ level by a Tukey-Kramer test.
\end{tabular}

\section{Discussion}

Knoll and Anderson [32] reported that autumn-underground planting of nine genotypes of Napiergrass in November led to shoot emergence in the following spring, although no shoot emergence was evident in the autumn they were planted in Tifton, GA, USA [32]. We observed the same phenomenon of shoot emergence of dwarf Napiergrass in the present study. In addition, dwarf Napiergrass grassland was successfully established by planting mature stem cuttings in Florida, USA in December [14]. The new establishment method for dwarf Napiergrass by sowing IR in the winter season using the same approach as for summer establishment of sugarcane in Kyushu, Japan proved successful in experimental fields over a two-year evaluation, confirming the effectiveness of field propagation of cuttings, which was also demonstrated in two beef cow-calf producer fields, including one on a remote island. Although the Goto site was located at the lowest altitude, the missing plant rate of dwarf Napiergrass at the site was higher than at both the Shimabara and Isahaya sites, with the exception of the IR-20 cm plot in Shimabara. Covering of the plants with soil in Goto was not completed due to rain at planting and the medium-coarse soil properties of the site, which presumably increased the missing plant rate compared to the other two sites, with the exception of the IR-20 cm plot in Shimabara.

The missing plant rate was higher at a $20 \mathrm{~cm}$ depth than at a $10 \mathrm{~cm}$ depth, which suggested the effectiveness of a $10 \mathrm{~cm}$ planting depth for dwarf Napiergrass stem cuttings that normally have more than 10 nodes. However, underground storage of one-node stem sections at depths of 10, 25 and $40 \mathrm{~cm}$ revealed that sections stored at $10 \mathrm{~cm}$ depth had the lowest plant emergence rate [28]. Iki et al. [28] temporarily stored one-node stem cuttings underground in the winter season to dig out in the following spring, recommending the $25 \mathrm{~cm}$ depth as leading to the highest emergence of nursery plants. On the other hand, in the current research, where stem cuttings were kept underground with no digging out and transplanting the following spring, a $10 \mathrm{~cm}$ depth is recommended, judging from the lowest missing plant rate. The difference in the optimum stored depth between the previous study [28], which used one-node stem cuttings, and the current study using stem cuttings typically having more than 10 nodes might reflect the greater susceptibility of one-node stem cuttings to dehydration stress at the shallower depth. Knoll and Anderson [33] also reported that the emergence of Napiergrass were higher in 10-node sections than in sections with one or two nodes. Stem nodes of normal-type Napiergrass can be stored underground in the winter period when the minimum temperature is maintained above $5{ }^{\circ} \mathrm{C}$ [33]. While soil temperature was not monitored in the current study, stem cuttings stored at a $10 \mathrm{~cm}$ depth are expected to emerge the following spring if covering plants with soil was sufficient to keep soil temperature above $5{ }^{\circ} \mathrm{C}$. Diurnal variation of temperature was presumably less in the underground soil than in the air. Since the length of stem cuttings may influence the viability of tiller buds, it is necessary to conduct more detailed experiments to investigate the emergence of dwarf Napiergrass from cuttings that overwintered in the field. The plant density the following spring ranged from 2 to 3.8 plants $/ \mathrm{m}^{2}$ in the current study, or a density of over 2 plants $/ \mathrm{m}^{2}$. Ordinary manual transplanting typically leads to a density of 2 plants $/ \mathrm{m}^{2}$ [2,5,8,34], so the current method led to plant emergence comparable to other reports.

Utamy et al. [26] reported that transplanting of nursery plants of dwarf Napiergrass using a Welsh onion planter did not reduce labor compared to manual transplanting, possibly due to a limited area for transplanting. As shown in Table 3, the labor in the current study showed a dramatic reduction $(66 \%)$ 
by propagating cuttings of dwarf Napiergrass in the winter, compared to manual transplanting. As the field propagation of dwarf Napiergrass in winter does not require the time-consuming preparation required by cell-tray nursery production [26,27], or a specific planting machine, such as a Napiergrass planter [25], Welsh onion planter [26], potato planter [27] or vegetable machine [27], it appears simpler and more practical. Moreover, since this method is performed in the agricultural off-season, it is desirable both for its efficiency in decreasing the workload and for avoiding additional work in the hot summer season.

Repeated weed control is essential until the leaf canopy of dwarf Napiergrass is well established [35]. Though living mulch of IR led to a slight decrease in DM yield of forage maize (Zea mays L.), this method proved to be effective for weed control [36]. For dwarf Napiergrass cuttings planted in the winter, plant emergence should compete with weeds the following spring. However, as shown in Table 2, sowing of IR when stem cuttings of dwarf Napiergrass are planted could suppress weed growth and produce herbage biomass in the following spring without disturbing the emergence of dwarf Napiergrass, which could lead to an annual forage production system. Total DM yield of an annual forage production system combining IR with dwarf Napiergrass in this region was determined to be $27-34 \mathrm{Mg} / \mathrm{ha}$ [1]. The current research revealed that a $10 \mathrm{~cm}$ depth of November planting of cuttings at the same time as sowing of IR led to a yield of up to $30 \mathrm{Mg} / \mathrm{ha}$ with a comparable contribution of dwarf Napiergrass and IR to annual yield, which was similar to the annual total DM yield of our previous research [1].

\section{Conclusions}

Dwarf Napiergrass was established by planting stem cuttings with soil in the winter in the same way that sugarcane is established in the summer, yielding a plant density of over 2 plants $/ \mathrm{m}^{2}$. Moreover, the technique proved to be a simple and labor-saving method, compared with manual or mechanical transplanting of nursery plants. Sowing of IR at the same time as planting cuttings of dwarf Napiergrass could control spring weed growth without disturbing emergence of the grass species, suggesting that a double cropping forage production system could be achieved in the region.

Acknowledgments: The authors are sincerely grateful to Kyohei Ninomiya and to the permanent and temporary staff of the Forage Crops and Grassland Section of the Nagasaki Agricultural and Forestry Technical Development Center for their contributions to conducting the present research. The authors thank Sakae Hirano, Yuichi Tagawa and Yasutaka Watanabe for their help in cultivation of dwarf Napiergrass in beef cow-calf producers' fields. Yasuyuki Ishii received funds (Grant-in-Aid for Scientific Research (C), Japan Society for the Promotion of Science, No. 16K07577) covering the costs for open access publishing.

Author Contributions: Satoru Fukagawa and Yasuyuki Ishii conceived and designed the experiments; Satoru Fukagawa performed the experiments and analyzed the data; and Satoru Fukagawa and Yasuyuki Ishii wrote the paper.

Conflicts of Interest: The authors declare no conflict of interest.

\section{References}

1. Fukagawa, S.; Hirokawa, J.; Ohkushi, M.; Ishii, Y. Fermentative quality and feed characteristics of dwarf napiergrass (Pennisetum purpureum Schumach). J. Jpn. Grassl. Sci. 2010, 56, 26-33. (In Japanese)

2. Fukagawa, S.; Ogasawara, S.; Ishii, Y. Defoliation management aiming at suitable quality herbage production of dwarf napiergrass (Pennisetum purpureum Schum.) in northern Kyushu. J. Jpn. Grassl. Sci. 2015, 61, 59-66. (In Japanese)

3. Ishii, Y.; Tudsri, S.; Ito, K. Potentiality of dry matter production and overwintering ability in dwarf napiergrass introduced from Thailand. Bull. Fac. Agric. Miyazaki Univ. 1998, 45, 1-10.

4. Ishii, Y.; Sunusi, A.A.; Mukhtar, M.; Idota, S.; Fukuyama, K. Herbage quality of dwarf Napier grass under a rotational cattle grazing system two years after establishment. In Proceedings of the Satellite Workshop of the XXth International Grassland Congress, Glasgow, Scotland, 3-6 July 2005; p. 150. 
5. Utamy, R.F.; Ishii, Y.; Idota, S.; Harada, N.; Fukuyama, K. Adaptability of dwarf napiergrass under cut-and-carry and grazing systems for smallholder beef farmers in southern Kyushu, Japan. J. Warm Reg. Anim. Sci. 2011, 54, 87-98.

6. Bilal, M.Q. Effect of molasses and corn as silage additives on the characteristics of Mott dwarf elephant grass silage at different fermentation period. Pakistan Vet. J. 2009, 29, 19-23.

7. Clavero, T.; Razz, R. Effects of biological additives on silage composition of Mott dwarf elephantgrass and animal performance. Rev. Cient. 2002, 12, 313-316.

8. Fukagawa, S.; Maruta, S.; Mine, Y.; Ishii, Y. Effect of season and frequency of defoliation on dry matter yield, herbage quality, fermentation quality of round-bale silage and wintering ability in dwarf napiergrass (Pennisetum purpureum Schumach). J. Warm Reg. Anim. Sci. 2016, 59, 105-113. (In Japanese)

9. Fukagawa, S.; Ishii, Y.; Hattori, I. Fermentation quality of round-bale silage as affected by additives and ensiling seasons in dwarf napiergrass (Pennisetum purpureum Schumach). Agronomy 2016, 4, 48. [CrossRef]

10. Fukagawa, S.; Ishii, Y.; Kataoka, K. Round-bale silage harvesting and processing effects on overwintering ability, dry matter yield, fermentation quality, and palatability of dwarf napiergrass (Pennisetum purpureum Schumach). Agronomy 2017, 7, 10. [CrossRef]

11. Ruiz, T.M.; Sanchez, W.K.; Staples, C.R.; Sollenberger, L.E. Comparison of 'Mott' dwarf elephantgrass silage and corn silage for lactating dairy cows. J. Dairy Sci. 1992, 75, 533-543. [CrossRef]

12. Dos Santos, R.J.C.; de Andrade Lira, M.; Guim, A.; dos Santos, M.V.F.; Junior, J.C.B.D.; de Leão de Mello, A.C. Elephant grass clones for silage production. Sci. Agric. 2013, 70, 6-11. [CrossRef]

13. Woodard, K.R.; Prine, G.M.; Bates, D.B. Silage characteristics of elephantgrass as affected by harvest frequency and genotype. Agron. J. 1991, 83, 547-551. [CrossRef]

14. Woodard, K.R.; Prine, G.M.; Bates, D.B.; Chynoweth, D.P. Preserving elephantgrass and energycane biomass as silage for energy. Biores. Technol. 1991, 36, 253-259. [CrossRef]

15. Crestani, S.; Filho, H.M.N.R.; Miguel, M.F.; Almeida, E.X.; Santos, F.A.P. Steers performance in dwarf elephant grass pastures alone or mixed with Arachis pintoi. Trop. Anim. Health Prod. 2013, 45, 1369-1374. [CrossRef] [PubMed]

16. Ishii, Y.; Mukhtar, M.; Idota, S.; Fukuyama, K. Rotational grazing system for beef cows on dwarf napiergrass pasture oversown with Italian ryegrass for 2 years after establishment. J. Jpn. Grassl. Sci. 2005, 5, 223-234. [CrossRef]

17. Mukhtar, M.; Ishii, Y.; Tudsri, T.; Idota, S.; Sonoda, T. Grazing suitability of normal and dwarf napiergrasses transplanted on bahiagrass pasture. J. Jpn. Grassl. Sci. 2004, 50, 15-23.

18. Sollenberger, L.E.; Jones, C.S., Jr. Beef production from nitrogen-fertilized Mott dwarf elephantgrass and Pensacola bahiagrass pastures. Trop. Grassl. 1989, 23, 129-134.

19. Halim, R.A.; Shampazuraini, S.; Idris, A.B. Yield and nutritive quality of nine Napier grass varieties in Malaysia. Malays. J. Anim. Sci. 2013, 16, 37-44.

20. Khairani, L.; Ishii, Y.; Idota, S.; Utamy, R.F.; Nishiwaki, A. Variation in growth attributes, dry matter yield and quality among 6 genotypes of napiergrass used for biomass in year of establishment in southern Kyushu, Japan. Asian J. Agric. Res. 2013, 7, 15-25.

21. Macoon, B.; Sollenberger, L.E.; Moore, J.E. Defoliation effects on persistence and productivity of four Pennisetum genotypes. Agron. J. 2002, 94, 541-548.

22. Schank, S.C.; Chynoweth, D.P. The value of triploid, tetraploid, and hexaploid napier grass derivatives as biomass and (or) forage. Trop. Agric. 1993, 70, 83-87.

23. Williams, M.J.; Hanna, W.W. Performance and nutritive quality of dwarf and semi-dwarf elephantgrass genotypes in the south-eastern USA. Trop. Grassl. 1995, 29, 122-127.

24. Zalian, M.Z.; Yaakub, H.; Juson, S. Yield and nutritive quality of Napier (Pennisetum purpureum) cultivars as fresh and ensiled fodder. J. Anim. Plant Sci. 2018, 28, 63-72.

25. Sollenberger, L.E.; Prine, G.M.; Ocumpaugh, W.R.; Schank, S.C.; Kalmbacher, R.S.; Jones, C.S., Jr. Dwarf napiergrass: A high quality forage with potential in Florida and the tropics. Soil Crop. Sci. Soc. Fla. Proc. 1987, 46, 42-46.

26. Utamy, R.F.; Ishii, Y.; Idota, S.; Khairani, L.; Fukuyama, K. Development of mechanical methods for cell-tray propagation and field transplanting of dwarf napiergrass (Pennisetum purpureum Schumach). J. Agric. Rural Dev. Trop. Subtrop. 2016, 117, 11-19. 
27. Maruta, S. Grassland Establishment. Manual of Cultivation, Utilization and Grassland Establishment in Dwarf Napiergrass. Fukagawa, S., Maruta, S., Eds.; 2015. Available online: https:/ /www.pref.nagasaki.jp/e-nourin/ nougi/manual/nepia-manual.pdf (accessed on 20 June 2017).

28. Iki, Y.; Ishii, Y.; Fukagawa, S.; Idota, S. Effect of indoor and underground storage on efficient vegetative propagation of dwarf Napier grass (Pennisetum purpureum Schumach). Am. J. Plant Sci. 2016, 7, 1173-1179. [CrossRef]

29. Sollenberger, L.E.; Jones, C.S., Jr.; Albrecht, K.A.; Ruitenberg, G.H. Vegetative establishment of dwarf elephantgrass: Effect of defoliation prior to planting stems. Agron. J. 1990, 82, 274-278. [CrossRef]

30. Akwilin, J.P.T.; Takamura, T.Y. Sugarcane production, processing and marketing in Tanzania. Afr. Study Monogr. 1998, 19, 1-11.

31. Mukhtar, M.; Ishii, Y.; Tudsri, S.; Idota, S.; Sonoda, T. Dry matter productivity and overwintering ability of the dwarf and normal napiergrasses as affected by the planting density and cutting frequency. Plant Prod. Sci. 2003, 6, 65-73. [CrossRef]

32. Knoll, J.E.; Anderson, W.F. Vegetative propagation of Napiergrass and Energycane for biomass production in the South United States. Agron. J. 2012, 104, 518-522. [CrossRef]

33. Inanaga, S.; Ito, K.; Yajima, T.; Inoue, H.; Hatano, S. Effect of temperature on viability and elongation of lateral bud of Napier grass (Pennisetum purpureum Schumach). J. Jpn. Crop Sci. 1990, 59, 747-751. [CrossRef]

34. Ishii, Y.; Dong-Jing, K.; Yamano, A.; Idota, S.; Fukuyama, K. Adaptability and extension activity of dwarf napiergrass in southern Kyushu and elsewhere since its introduction to Japan 15 years ago. Development and Impact of Sown Temperate Species. In Proceedings of the 22nd International Grassland Congress, Sydney, Australia, 15-19 September 2013; New South Wales Department of Primary Industry: New South Wales, Australia, 2013.

35. Utamy, R.F.; Ishii, Y.; Idota, S.; Khairani, L. Effect of weed control management on herbage yield, quality and wintering ability in the established dwarf napiergrass (Pennisetum purpureum Schumach). J. Warm Reg. Soc. Anim. Sci. 2012, 55, 17-26.

36. Sato, S.; Tateno, K.; Kobayashi, R.; Sakamoto, K. Control of spiny Amaranth (Amaranthus spinosus L.) with Italian ryegrass (Lolium multiflorum Lam.) living mulch in forage corn (Zea mays L.). J. Weed Sci. Technol. 1998, 43, 317-327. [CrossRef] 